\title{
PRIESTOROVÁ VARIABILITA INTENZITY NÁDOROVÝCH OCHORENÍ NA SLOVENSKU
}

\author{
Alena Dubcová, Katarína Vilinová, Lucia Mikulová
}

\begin{abstract}
Health is the greatest treasure of every individual in today's society. People who have good health have better conditions to achieve their goals than those with various physical and mental difficulties. They create the basic development potential of different hierarchical regions. Tumor diseases in the world's economically advanced countries are the second most common cause of death after cardiovascular disease. These diseases are the main cause of mortality, particularly early and disability, in many regions. The aim of the contribution is to identify, on the basis of mortality and incidence development, regions with a high incidence of cancer. Cancer diseases known as cancer are the second most serious cause of death with a share of 25,35\% (2017) in Slovakia as well. Slovakia belongs besides Hungary and Croatia to the three countries in the EU with the highest mortality rates for cancer. In 2017, 13,666 people died of this disease. The number of reported new cases is constantly increasing. In order to establish effective preventive measures for primary and secondary prevention, it is necessary to know the level of mortality and incidence of cancer in the regions of Slovakia, which is the purpose of the contribution.
\end{abstract}

Keywords: cancers, mortality, incidence, region, Slovakia

\section{Úvod}

Zdravie je najväčším pokladom každého jedinca v súčasnej spoločnosti. Ludia, ktorí disponujú dobrým zdravím, majú lepšie podmienky na dosiahnutie svojich ciel'ov ako tí, ktorí sa boria s rôznymi fyzickými a psychickými t’ažkost’ami. Zdraví l’udia vytvárajú základný potenciál rozvoja regiónov na rôznej hierarchickej úrovni. Zdravie je považované za súčast' prosperity spoločnosti a za podmienku trvalo udržatel’ného rozvoja každého územia (Vilinová, 2012).

Nádorové ochorenia v ekonomicko-vyspelých štátoch sveta sú po kardiovaskulárnych chorobách druhou najčastejšou príčinou smrti. Zdravie je ovplyvňované predispozíciou a množstvom sociálnych, ekonomických a enviromentálnych faktorov. Ich negatívne pôsobenie môže viest' $\mathrm{k}$ vzniku choroby až k úmrtnosti. Nevhodný životný štýl, pracovné zat'aženie, stres, nízka fyzická aktivita, nezdravá životospráva a stravovanie, konzumácia alkoholu, fajčenie a d’alšie vplyvy životného a pracovného prostredia sa odrážajú na zvýšení chorobnosti obyvatel'stva najmä chronickými ochoreniami. K najzávažnejším 
chronickým (civilizačným) chorobám patria kardiovaskulárne, nádorové, chronické dýchacie a metabolické (cukrovka) ochorenia. Tieto ochorenia sú hlavnou príčinou úmrtnosti, hlavne predčasnej a zdravotného postihnutia obyvatel'ov mnohých regiónov. Výrazne znižujú kvalitu života obyvatel’ov, znižujú kvalitu l'udského potenciálu pre hospodárske aktivity a zvyšujú nároky na zdravotnú i sociálnu starostlivost' v regiónoch. Ciel’om príspevku je na základe úmrtnosti a incidencie vytypovat' regióny, s vysokou mierou nádorového ochorenia, ktorým je potrebné venovat' zvýšenú zdravotnícku pozornost' z aspektu primárnej a sekundárnej starostlivosti.

\section{Teoreticko-metodické východiská}

Nádorové ochorenia sú ovplyvňované genetickými ale aj rizikovými faktormi. Genetická predispozícia rakoviny je u 5-10 \% zo všetkých diagnostikovaných nádorov (Závodná a kol., 2015). Rakovina nie je priamo dedičná. Riziko vzniku nádoru u jednotlivca je ovplyvňované okrem interných, genetických a epigenetických zmien (t. z. zmien génovej expresie vznikajúcej bez zmeny primárnej genetickej informácie) aj kombináciou viacerých faktorov $\mathrm{z}$ vonkajšieho prostredia, ktoré vzájomne spolupôsobia rôznymi a často nepredvídatel'nými spôsobmi. K najznámejším faktorom, ktoré ovplyvňujú vznik tohto ochorenia patria - fajčenie (plúca, kolorektálny karcinóm, žalúdok a rakovina pečene), nadváha, obezita a fyzická nečinnost' (rakovina prsníka a kolorekta) a infekcia (pečeň, žalúdok a karcinóm krčka maternice). Rizikové faktory pre značnú variabilitu sú predmetom záujmu viacerých autorov. Podl'a Lučana, (2003) úmrtnost' na onkologické ochorenia je výsledkom spolupôsobenia viacerých faktorov ako sú dedičné vlohy, životospráva, životné prostredie, úroveň liečebnej a diagnostickej starostlivosti Mládek a kol. (2006) k najvýznamnejším vonkajším faktorom začleňuje demografické a biologické (napr. vek, pohlavie...), socio-ekonomické faktory (napr., vzdelanie, povolanie, životný štýl, sociálny status...). Napríklad životný štýl obyvatel'stva je v súčastnosti do vel'kej miery ovplyvnený ponukou a dostupnost'ou maloobchodných ret’azcov, ktoré na jeho formovaní majú značný vplyv (Trembošová et al., 2016, Trembošová, Vlačuhová, 2016). Okrem toho $\mathrm{k}$ dôležitým faktorom patria aj prostredie (napr. životné a pracovné) a zdravotníctvo (napr. zdravotné strediská, onkologické centrá, počet lekárov, lôžok...).

Populácia v ekonomický - rozvinutých štátoch je charakteristická procesom starnutia, t. z. zvyšovaním priemerného veku života. Na tento fakt poukazuje napr. Torre et al. (2015), podl'a ktorých rast tohto onemocnenia je spojený s procesom starnutia (predlžovaním priemerného veku života) a tiež s rastúcou prevalenciou zavedených rizikových faktorov, spojených $\mathrm{s}$ urbanizáciou a hospodárskym rozvojom. Autori zároveň poukazujú i na to, že všeobecným uplatňovaním účinných preventívnych opatrení ako je kontrola tabaku, očkovanie a používanie skorých detekčných testov, atd'., podstatnej časti ochorení a úmrtí by sa dalo predíst'. 
Väčšinou týmto onemocnením a smrtel’ným potenciálom sú ohrozené osoby stredného a staršieho veku. Nezdravý životný štýl so zvyšujúcim sa vekom (už od stredných vekových kategórii) sa odráža $\mathrm{v}$ náraste chorobnosti a tým aj úbytku zdravia v populácii (Vobr a kol., 2012). K d’alším autorom študujúcim vzt'ah rakoviny a starnutia populácie patrí napr. White et al., 2014. Podl'a nich stredná doba života je obdobím života, kde je vysoká prevalencia viacerých rizikových faktorov rakoviny a počet prípadov rakoviny začína rást'. Súčasné výskumy poukazujú na to, že pre väčšinu dospelých rakovina nemusí byt' nevyhnutným dôsledkom starnutia. Intervencie, ktoré podporujú zdravé životné prostredie, pomáhajú l'ud'om zvládnut' chronické stavy a podporujú ich zdravé správanie, môžu ul'ahčit' zdravší prechod z obdobia stredného života do staršieho veku a znížit' tak pravdepodobnost' výskytu rakoviny. Pravdaže, vznik rôznych typov rakoviny ovplyvňujú i d'alšie faktory ako napr. sociálno-ekonomické prostredie, kvalita životného prostredia a hlavne životný štýl, a d'alšie. Možno k nim zaradit' faktor nezamestnanosti, v úzkej väzbe na zvýšenú mieru rizika chudoby, ktorú na regionálnej úrovni v svojich prácach analyzujú Veselovský et al. (2016) a Veselovský, Šolcová (2011). Na ich základe je možné špecifikovat' priestorové rozdiely tohto onemocnenia či už z hl'adiska miery výskytu úmrtnosti, alebo vo vzt’ahu k rôznym špecifikám (napr. vekové skupiny, národnost', povolanie, vzdelanost' atd'.).

Priestorové väzby nádorových ochorení na území Slovenska sledovalo viacero autorov. Letkovičová, Rehák a kol. (1999) študovali výskyt rakoviny v zázemí Atómovej elektrárne Mochovce do $20 \mathrm{~km} \mathrm{t}$. z. v havarijnom pásme. Úmrtnosti na rakovinu na úrovni okresov Slovenska sledovali Vilinová a kol. (2017). Autorka túto problematiku spracovala aj na úrovní obcí Nitrianskeho samosprávneho kraja (Vilinová, 2012). Kážmer a Križan (2010) v okresoch Slovenka analyzovali rozmiestnenie na rakoviny prostraty.

Najdôležitejšie a najčastejšie používané indikátory pre meranie zdravia a choroby populácie sú úmrtnost', incidencia a prevalencia. Incidencia (počet novovzniknutých prípadov) je indikátor dynamiky začiatku choroby infekčných aj chronických chorôb, signalizuje riziko, ktorému je populácia vystavená. Pre účely príspevku boli získané a spracované dáta úmrtnosti 2006-2016 a incidencie nádorových ochorení za obdobie 2006-2010. Pre kolísavost' dát boli jednotlivé obdobia spriemerované. Rok 2010 je posledným rokom zverejnenia dát incidencie nádorového ochorenia Národným centrom zdravotníckych informácií SR. Incidencia je podobne ako prevalencia ukazovatel'om morbility (chorobnosti). Pod incidenciou sa $\mathrm{v}$ epidemiológii rozumie počet novovzniknutých ochorení (alebo hlásených, registrovaných prípadov onemocnenia) počas určitého obdobia (rok) a prepočítava sa na 1000,10000 alebo 100000 osôb exponovanej populácie.

Ďalším dôležitým indikátorom je aj hrubá miera úmrtnosti, ktorú možno charakterizovat' podl'a Šulcovej a kol. (2012), ako základnú nenahraditelnú informáciu o výskyte choroby a súčasne aj o zdravotnom stave populácie. Považuje sa tiež za dôležitú informáciu pri rozhodovaní o prioritách v zdravotníctve ako aj v 
spoločnosti, a taktiež je nenahraditel'ná pre epidemiologické, demografické a štatistické sledovania. Z absolútneho počtu hlásených ochorení sa nevie posúdit' nakol'ko je problém závažný pre populáciu území rôznych hierarchických úrovní a preto boli využité miery hrubej incidencie a štandardizovanej incidencie registrovaných ochorení. Štandardizovaná miera incidencie umožňuje neskreslené porovnanie incidencie populácií s rôznou vekovou štruktúrou, v ktorých je celková úroveň incidencie ovplyvnená odlišným zastúpením určitých vekových skupín $\mathrm{s}$ rôznou úrovňou incidencie prepočítaná na 100000 obyvatel'ov. Pod hrubou incidenciou sa rozumie počet ochorení pripadajúcich na 100000 obyvatel'ov daného územného celku (v našom prípade okresu).

\section{Priestorová variabilita intenzity nádorového ochorenia}

Rakovina je v ekonomicko-vyspelých štátoch sveta po kardiovaskulárnych chorobách druhou najčastejšou príčinou úmrtí, nevynímajúc ani Slovensko. Na Slovensku ročne zomrie cez 53 tisíc. obyvatel'ov. Z toho viac ako tri štvrtiny $(76,30 \%)$ zomrie na chronické ochorenia. Nádorové ochorenia predstavujú z tejto skupiny ochorení jednu tretinu $(33,22 \%$ r. 2016). Chronické resp. neinfekčné ochorenia sú charakteristické vyššou predčasnou úmrtnost'ou. So starnutím populácie a predlžovaním priemernej dížky života $\mathrm{v}$ zdraví sa každé úmrtie pred 75. rokom života pokladá za predčasné. V SR v roku 2017 bolo 45,06 \% úmrtí do veku 75 rokov z toho na rakovinu pripadla jedna tretina $(33,74 \%)$. Predčasne na nádorové ochorenia zomrelo $62,65 \% \mathrm{z}$ celkovej úmrtnosti na tento typ choroby (s výraznými rozdielmi medzi mužmi $(60,51 \%)$ a ženami $(39,49 \%)$. Na Slovensku je priestorové rozmiestnenie úmrtnosti značne nerovnomerné. Pozitívne je, že väčšina okresov Slovenska $(70,89 \%)$ je charakteristická úrovňou vel'mi nízkej až priemernej úmrtnosti (tab. 1). V týchto okresoch zomrelo 50,53\% populácie Slovenska. Kým v okresoch s vysokou a vel'mi vysokou úmrtnost’ou, ktorým patrí len jedna pätina (23 t. z. $29,11 \%$ ) z počtu okresov, zomrela skoro až jedna polovica $(49,47 \%)$ celkového počtu zomretých.

Tab. 1: Typy hrubej miery úmrtnosti Slovenska v období 2006 - 2010 Table 1: Types of mortality of Slovakia in the period 2006-2010

\begin{tabular}{|c|c|c|c|c|c|c|}
\hline \multirow[t]{2}{*}{ Typ úmrtnosti } & \multicolumn{2}{|c|}{$\begin{array}{l}\text { Ø počet } \\
\text { okresov }\end{array}$} & \multicolumn{2}{|c|}{ Ø počet zomretých } & \multicolumn{2}{|c|}{ Ø počet obyvatel'ov } \\
\hline & abs. & $\%$ & abs. & $\%$ & abs. & $\%$ \\
\hline Vel'mi nízka & 20 & 25 & 5767 & 11 & 1499471 & 28 \\
\hline Nízka & 19 & 24 & 9561 & 18 & 1131121 & 21 \\
\hline Priemerná & 17 & 22 & 11623 & 22 & 1126570 & 21 \\
\hline Vysoká & 7 & 9 & 6093 & 11 & 424025 & 8 \\
\hline Vel'mi vysoká & 16 & 20 & 20292 & 38 & 1227877 & 23 \\
\hline Spolu & 79 & 100 & 53336 & 100 & 5409064 & 100 \\
\hline
\end{tabular}

Zdroj: ŠÚ SR, 2018 
Priestorovo vytvára úmrtnost' dva výrazne regióny - väčší začína v okrese Levice a uhlopriečkou pokračuje do okresu Poprad. Druhý, menší tvoria okresy Podunajskej roviny (mapa 1). Vel'mi vysoká miera úmrtnosti je vokresoch Trnava, Lučenec, Žarnovica, mesto Košice, ktoré vystupuje izolovane.

Mapa. 1: Priemerná úmrtnost' obyvatel’ov v okresoch SR za obdobie $2006-2010$ Map. 1: Average population mortality in districts of the SR for the period 20062010

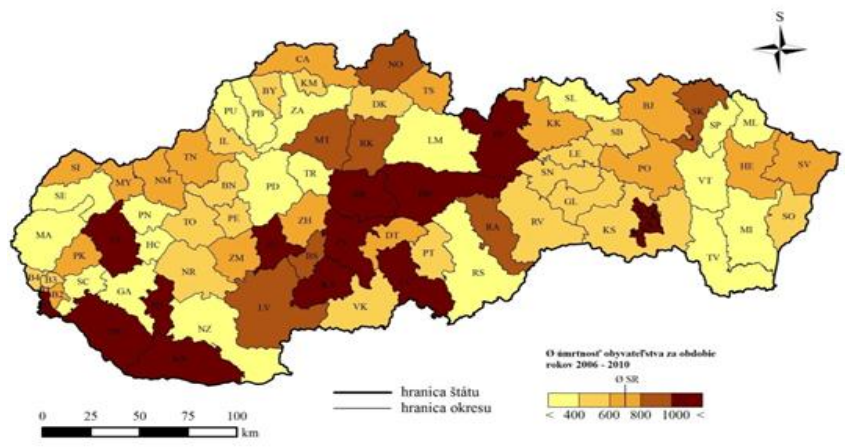

Zdroj: ŠÚ SR, 2018, spracovali autori

Tab. 2: Vývoj úmrtnosti Slovenska v období 2006 - 2016

Table 2: Progress of mortality in Slovakia in the period $2006-2016$

\begin{tabular}{|c|c|c|c|c|c|c|}
\hline \multirow[t]{2}{*}{ Rok } & \multirow{2}{*}{$\begin{array}{l}\text { Stredný stav } \\
\text { obyvatel'stva }\end{array}$} & \multirow{2}{*}{$\begin{array}{c}\text { Počet } \\
\text { obyvatel'ov } \\
\text { k 31.12. }\end{array}$} & \multicolumn{2}{|c|}{ Zomrelí celkovo } & \multicolumn{2}{|c|}{$\begin{array}{l}\text { Zomrelí na } \\
\text { zhubné nádory }\end{array}$} \\
\hline & & & abs. & $\%$ & abs. & $\%$ \\
\hline 2006 & 5396168 & 5393637 & 55236 & 9,49 & 11149 & 2,06 \\
\hline 2007 & 5404784 & 5400998 & 53856 & 9,96 & 11867 & 2,21 \\
\hline 2008 & 5416958 & 5412254 & 53164 & 98 & 11891 & 2,21 \\
\hline 2009 & 5429763 & 5424925 & 52913 & 4 & 11831 & 2,20 \\
\hline 2010 & 5397251 & 5435273 & 53445 & 9,90 & 12185 & 2,26 \\
\hline 2011 & 5405338 & 5404322 & 51903 & 9,60 & 12071 & 2,23 \\
\hline 2012 & 5412008 & 5410836 & 52437 & 9,69 & 12197 & 2,25 \\
\hline 2013 & 5417750 & 5415949 & 52089 & 9,61 & 355 & 2,47 \\
\hline 2014 & 5421432 & 5421349 & 51346 & 9,47 & 13469 & 2,48 \\
\hline 2015 & 5429824 & 5426252 & 53826 & 9,91 & 13657 & 2,52 \\
\hline 2016 & 5437754 & 5435343 & 52351 & 9,63 & 13564 & 2,49 \\
\hline $\begin{array}{l}\text { priemer } \\
2006-2016\end{array}$ & 366 & 5416467 & 52597 & 9,7 & 12505 & 2,31 \\
\hline 2017 & 5437754 & 5443120 & 53914 & 9,91 & 13666 & 2,51 \\
\hline
\end{tabular}

Zdroj: ŠÚ SR, 2018, 
Nádorové ochorenia predstavujú skupinu ochorení, ktoré sa vyznačujú rovnakými základnými charakteristikami, ktorými sú nekontrolovatel'ný rast a šírenie abnormálnych buniek v organizme. Existuje cca 200 typov rakoviny. Rôzne rizikové faktory prispievajú $\mathrm{k}$ rozvoju ochorenia na rôznych miestach orgánov tela. V období dekády rokov 2006-2016 úmrtnost' na túto chorobu podobne ako aj celková úmrtnost' si udržujú stabilnú úroveň s miernymi výkyvmi (tab. 2). Za toto obdobie na rakovinu zomrelo 137563 l'udí, z toho prevažovali muži v pomere 78 844:58 719 žien.

Priestorové rozmiestnenie úmrtnosti na nádorové ochorenia vykazuje značné rozdiely oproti hrubej úmrtnosti. Kým vysoká hrubá miera úmrtnost' sa prejavuje hlavne $\mathrm{v}$ centrálnej časti Slovenska, špecifická úmrtnost' na nádorové ochorenia sa koncentruje najmä do pol'nohospodársko-priemyselných oblastí Slovenska - okresy Podunajskej a Východoslovenskej nížiny. Vyššie hodnoty dosahuje v Podunajskej nížine a malom regióne tvorenom priemyselnými okresmi Prievidza, Žilina, Trenčín a na východe Slovenska okresom Prešov (mapa 2).

Mapa 2: Špecifická úmrtnost' obyvatel'stva na nádorové ochorenia SR v období $2006-2010$

Map 2: Specific mortality of the population on cancer diseases of the Slovak Republic in 2006-2010

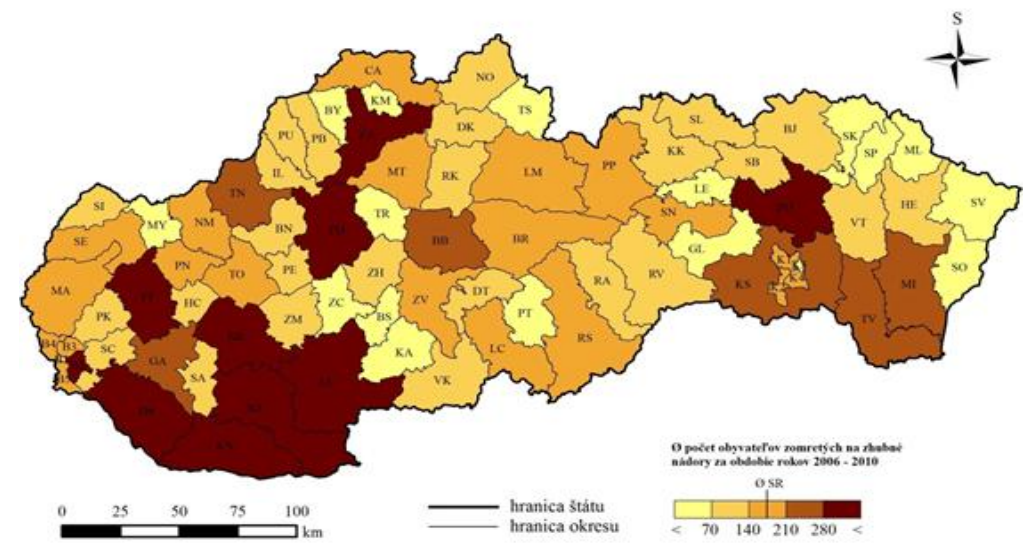

Zdroj: ŠÚ SR, 2018, spracovali autori

Vysoká a vel’mi vysoká úroveň úmrtnosti na nádorové ochorenia je v 16 okresoch, kde žije 37,04\% populácie Slovenka. Na tento typ choroby tu priemerne ročne zomrelo 4648 l'udí, čo predstavuje takmer dve pätiny $(39,18 \%$ z úmrtí na rakovinu na Slovensku v období rokov 2006-2010. Pre ostatnú čast' Slovenska je charakteristická priemerná až vel'mi nízka úmrtnost' na karcinogénne ochorenia (mapa 2 a tab. 3). 
Tab. 3: Typy úmrtnosti na nádorové ochorenia Slovenska v období $2006-2010$ Table 3: Types of mortality on cancer of Slovakia in the period 2006-2010

\begin{tabular}{|l|r|r|r|r|r|r|}
\hline \multirow{2}{*}{ Typ úmrtnosti } & \multicolumn{2}{|c|}{$\boldsymbol{\varnothing}$ počet okresov } & \multicolumn{2}{c|}{$\begin{array}{c}\text { Ø počet } \\
\text { zomretých na } \\
\text { nádory }\end{array}$} & \multicolumn{2}{c|}{ Ø počet obyvatel'ov } \\
\cline { 2 - 8 } & \multicolumn{1}{|c|}{ abs. } & \multicolumn{1}{c|}{$\%$} & \multicolumn{1}{c|}{ abs. } & \multicolumn{1}{c|}{$\%$} & \multicolumn{1}{c|}{ abs. } & \multicolumn{1}{c|}{$\%$} \\
\hline Vel'mi nízka & 17 & 22 & 951 & 8 & 456590 & 8 \\
\hline Nízka & 26 & 33 & 2993 & 25 & 1454137 & 27 \\
\hline Priemerná & 20 & 25 & 3270 & 28 & 1494755 & 28 \\
\hline Vysoká & 6 & 8 & 1371 & 12 & 648461 & 12 \\
\hline Vel'mi vysoká & 10 & 13 & 3277 & 28 & 1355121 & 25 \\
\hline Spolu & 79 & 100 & 11862 & 100 & 5409064 & 100 \\
\hline
\end{tabular}

Zdroj: ŠÚ SR, 2018, spracovali autori

Neustále prebiehajúce zmeny vo výskyte zhubných nádorov si vyžadujú trvalé monitorovanie, čo sa osvedčilo aj pri skúmaní novotvarov vo vyspelých krajinách (Pleško, Diba, 2014). Počet novodiagnostikovaných prípadov nádorových ochorení je známy z dát Národného onkologického registra SR. Podl’a týchto databáz má incidencia malígnych nádorov vzostupný trend (graf 1).

Graf 1: Vývoj počtu registrovaných prípadov zhubných nádorov a trend štandardizovanej incidencie (WSR) v rokoch 1978 až 2010 v SR

Graph 1: Evaluation of cancer cases and the trend of the standardized incidence rates (WSR) since 1978 to 2010 in Slovakia

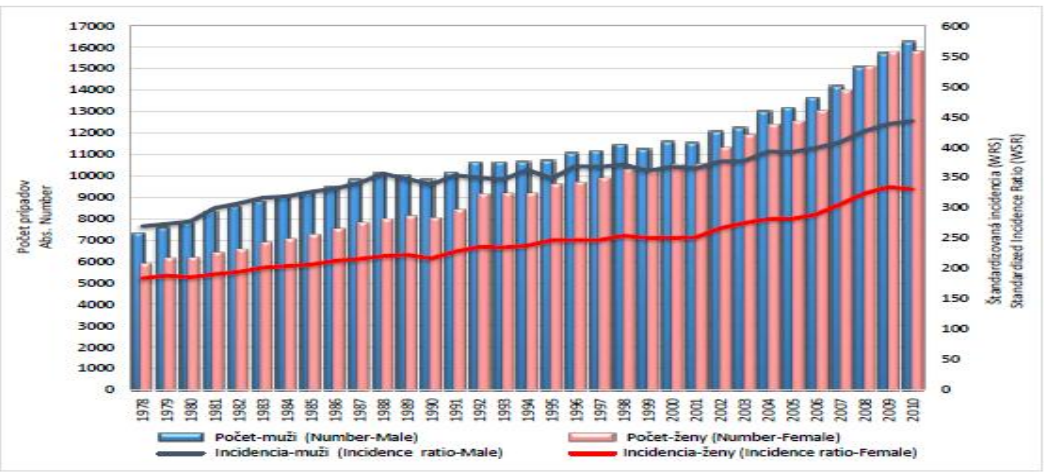

Zdroj: Diba, Hlava (2017)

Počet novodiagnostikovaných prípadov ochorení na Slovensku v roku 1968 dosiahol 12353 zhubných nádorov (z toho 6592 u mužov) - štandardizované 
hodnoty incidencie s použitím priamej metódy a svetovej štandardnej populácie predstavovali 238,5/100 000 mužov, v roku 198014138 prípadov (7 873 mužov), čiže 247,2/100 000 až po 22892 prípadov (z toho 11547 mužov) zhubných nádorov, diagnostikovaných v roku 2003 čiže 364,4/100 000 mužov (Ondrušová, 2007).

Tab. 4: Základné ukazovatele incidencie v rokoch 2006 - 2010

Table 4: Basic indicators of incidence in 2006-2010

\begin{tabular}{|c|c|c|c|c|c|c|c|}
\hline Rok & \multicolumn{3}{|c|}{$\begin{array}{c}\text { Počet } \\
\text { novoregistrovaných } \\
\text { prípadov }\end{array}$} & \multicolumn{2}{c|}{$\begin{array}{c}\text { Hrubá incidencia } \\
\text { na 100 000 } \\
\text { mužov / žien }\end{array}$} & \multicolumn{2}{c|}{$\begin{array}{c}\text { Štandardizovaná } \\
\text { incidencia na 100 000 } \\
\text { mužov / žien }\end{array}$} \\
\hline & spolu & muži & ženy & muži & ženy & muži & ženy \\
\hline 2006 & 25894 & 13241 & 12653 & 506,0 & 456,1 & 281,3 & 388,8 \\
\hline 2007 & 28131 & 14164 & 13967 & 540,4 & 503,0 & 408,8 & 306,2 \\
\hline 2008 & 30144 & 15055 & 15089 & 573,1 & 542,8 & 426,6 & 323,9 \\
\hline 2009 & 31466 & 15708 & 15758 & 596,5 & 565,8 & 438,3 & 334,7 \\
\hline 2010 & 32046 & 16251 & 15795 & 615,6 & 565,9 & 443,2 & 330,9 \\
\hline
\end{tabular}

Zdroj: NCZI SR, 2006, 2007, 2008, 2009, 2010.

V roku 2006 bolo zaregistrovaných 25894 novozistených ochorení, z toho u 13241 mužov. U mužov predstavuje hrubá incidencia 506,0 prípadov a štandardizovaná incidencia 388,8 prípadov (na $100 \quad 000$ mužov). V hrubej incidencii ide o 456,1 prípadov žien, štandardizovaná incidencia preukázala 281,3 prípadov u žien (na 100000 žien). Do roku 2010 na ich počet zvýšil na 16251 prípadov, čím sa zvýšila u mužov hrubá incidencia o 109,6 prípadov na 615,6/100000 mužov a štandardizovaná incidencia o 161,9/10000 mužov prípadov, kým u žien boli dosiahnuté nižšie hodnoty nárastu hrubej incidencie o 109,8/10000 žien $(565,9 / 100000$ žien), u štandardizovanej incidencie v jednotlivých rokoch je viditel'ný nárast novoregistrovaných prípadov. V prípade štandardizovanej incidencie u žien pozorujeme pozitívny pokles, naopak u mužov štandardizovaná incidencia narastá (tab. 4). Za obdobie rokov 2006-2010 bolo diagnostikovaných 147681 (z toho 74419 mužov a 73262 žien) prípadov tohto ochorenia. Na vývoj incidencie nádorových ochorení vplýva tiež rast strednej dížky života obyvatel'stva Slovenska. Za sledované obdobie stredná dížka života vzrástla u mužov z 70,40 v roku 2006 na 71,62 roku 2010 a u žien 78,20 na 78,84 roka.

Z priestorového hl'adiska možno vidiet' koreláciu medzi regiónmi s vysokou a vel'mi vysokou úmrtnost'ou a incidenciou na nádorové ochorenia. Regióny Podunajskej a Východoslovenskej nížiny a Košickej kotliny (okrem mesta Košice) sú charakteristické vysokými počtami novozniknutých nádorových ochorení ale aj úmrtnostou. Prekvapivo vysokú incidedenciu majú tatranské okresy Liptovský 
Mikuláš, Poprad a Banská Bystrica (mapa 3). Vel’mi vysoká incidencia je v okresoch s rozvinutou priemyselnou výrobou Trnava, Martin, Žilina, Trenčín a Prešov, viaceré z nich sú charakteristické vysokou úmrtnost’ou. Vysokou a vel'mi vysokou icidenciou je ohrozená takmer jedna tretina (23) okresov, v ktorých žije až $48,58 \%$ obyvatel'ov Slovenska. V týchto okresoch bolo novoregistrovaných prípadov viac ako polovica incidencie nádorových ochorení $(51,56 \%$ t. z. 15201 prípadov) Slovenska. Vysoké pracovné zat’aženie, neistota, stres, nízka fyzická zátaž, nezdravá výživa fajčenie, alkohol atd'. ako i predispozícia jedinca sa podpisujú na zvýšení chorobnosti.

Mapa 3: Intenzita novoregistrovaných ochorení na zhubné nádory SR v období $2006-2016$

Map 3: Intensity new registered diseases on cancers in SR in 2006 - 2016

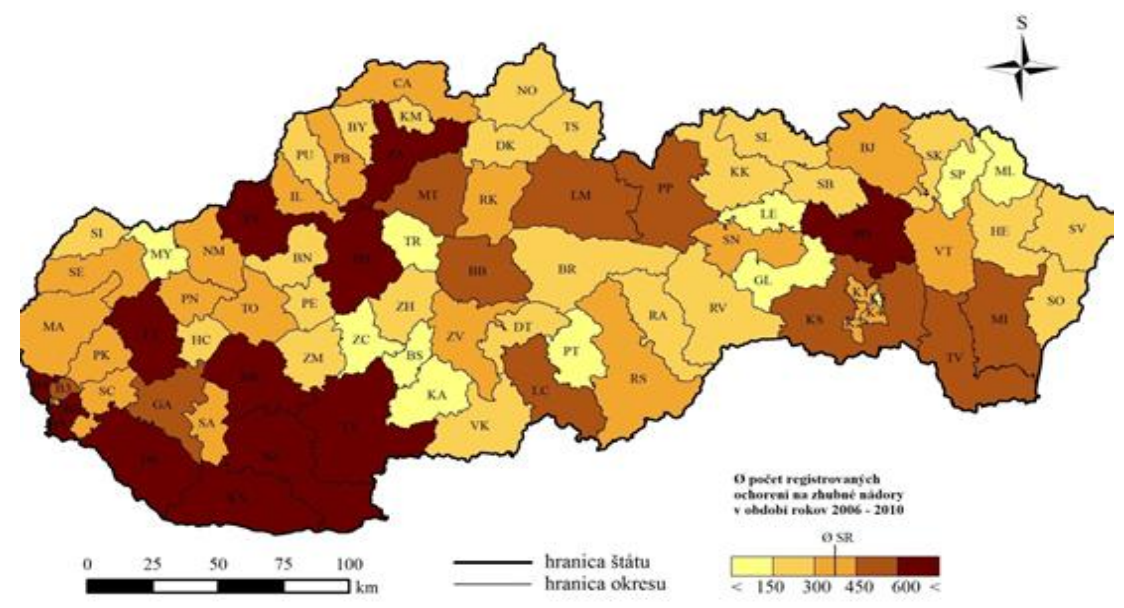

Zdroj: NCZI, 2018, spracovali autori

\section{Záver}

Dobré zdravie populácie je základom trvalo udržatel'ného ekonomického a sociálneho rastu každého regiónu a kvality života jeho obyvatel'ov. Avšak zdravie môže byt' narušené pôsobením ovplyvnitel'ných a neovplyvnitel'ných príčin, ktoré vedú $\mathrm{k}$ chorobe. Spôsob života a prostredie v ktorom človek žije, sa mení sa vplyvom jeho vedomej činnosti. Pretože značná čast' našej populácie nevenuje pozornost' starostlivosti o svoje zdravie, je potrebné vo zvýšenej miere venovat' úsilie na zmenu postojov obyvatel'ov voči vlastnému zdraviu najmä cestou zníženia výskytu rizikových faktorov (Avdičová, 2013). Nutné je zvýšit' tiež dôraz na osvetu a prevenciu medzi obyvatel'mi zameranú hlavne na zníženie nezdravého 
spôsobu života, zlepšením životného štýlu napr. formou zdravého stravovania, aktívnej pohybovej činnosti, vyhýbaním sa pitiu alkoholu, stresu atd'., pravidelne absolvovat' preventívne prehliadky, ktoré sú mimoriadne dôležité pre odhalenie rakovinových ochorení $\mathrm{v}$ ranných štádiách. Práve prognóza pacienta závisí predovšetkým od včasného záchytu nádorového ochorenia.

Predpokladá sa, že rakovina bude stále významnou príčinou chorobnosti a úmrtnosti v najbližších desat'ročiach vo všetkých regiónoch sveta. V súčasnosti na rakovinu najčastejšie muži zomierajú na zhubný nádor priedušnice, priedušiek a plúc, zhubné nádory kolorekta, hrubého čreva a prostaty. U žien je vysoká miera úmrtnosti na zhubné nádory prsníka, hrubého čreva, kolorekta a zhubné nádory priedušnice, priedušiek a plúc. Aj do budúcnosti sa očakáva vzostup výskytu týchto ochorení, vzhl'adom na stúpanie strednej dížky života obyvatel'stva a s tým súvisiaci nárast počtu obyvatel'stva vo vyšších vekových kategóriách (až 70\% zhubných nádorov sa vyskytuje u obyvatel'stva vo veku nad 55 rokov (Pleško, Diba, 2014).

Preto je potrebné venovat' zvýšenú zdravotnícku a osvetovú pozornost' najmä regiónom s vysokou úmrtnost'ou a incidenciou na rakovinové ochorenia. Študovat' a sledovat' predpokladané príčiny vzniku určitých nádorov. V prípade, že príčiny nie sú známe, je potrebné zamerat' sa na vyhl'adávanie včasných klinických štádií pomocou dobre organizovaného cieleného skríningu a adekvátneho liečenia. V roku 2018 Slovensko konečne prijalo Národný onkologický program (NOP). Prijatím a zavedením plánu bude mat SR ucelený program pre preventívne aktivity, kontrolu chorobnosti a úmrtnosti na onkologické ochorenia, ktorý bude do roku 2020 porovnatel'ný s aktivitami v ostatných krajinách EÚ.

\section{Literatúra}

ANALÝZA TRENDOV CHRONICKÝCH OCHORENÍ A MONITOROVANIE ZDRAVOTNÝCH INDIKÁTOROV V KONTEXTE 9 CIELOV GLOBÁLNEHO MONITOROVACIEHO RÁMCA DO ROKU 2025. [online]. 2018. [cit. 2018-09-09]. Dostupné na internete: http://www.hpi.sk/cdata/ Documents/Analyza_trendov_CHO_a_monitorovanie_RF.pdf

AVDIČOVÁ, M. a kol. 2013. Monitorovanie rizikových faktorov chronických chorôb v SR. Bardejov: Slovenská spoločnost' praktickej obezitológie, 2013. 175 s. ISBN 978-80-971460-0-9.

DIBA,CH. S. - HLAVA, P. 2017. Incidencia zhubných nádorov v Slovenskej republike 2010. Bratislava: NCZI, 2017. 188 s. ISBN 978-80-89292-55-4.

LUČAN, J. 2013. Onkochirurgia. [online]. 2018. [cit. 2018-09-09]. Dostupné na internete: https://docplayer.cz/30104755-Onkochirurgia-jaroslav-lucan.html

KAŽMER, L. - KRIŽAN, F. 2010. Priestorové rozšírenie mortality mužov na rakovinu prostaty na úrovni okresov v SR v rokoch 1996-2007. In Acta 
Geographica Universitatis Comenianae. ISSN 1338-6034, roč. 54, č. 1, s. 101 118.

MLÁDEK, J. a kol. 2006. Atlas obyvatel'stva Slovenska. Bratislava: Univerzita Komenského, 2006. 222 s. ISBN 80-223-2190-7.

LETKOVIČOVÁ, M. a kol. 1999. Zdravotný stav obyvatel'stva v okolí atómovej elektrárne Mochovce. Trnava: VÚJE, 1999. $128 \mathrm{~s}$.

ONDRUŠOVÁ, M. 2007. Epidemológia zhubných nádorov v SR. In Via practica, [online]. 2007, roč. 4 (S2), [cit. 2018-09-09]. Dostupné na internete: http://www.viapractica.sk/index.php?page=pdf_view\&pdf_id=2928\&magazine $\mathrm{id}=1$.

PEREČINSKÝ, S. - MARUŠČÁKOVÁ, V. - JANČOVÁ, A. 2017. Profesionálne nádorové ochorenie vo Východoslovenskom regióne. In Occupational Medicine/Pracovní Lékarství. ISSN. 0032-6291, 2017, roč. 69, č. 2, s. 7-11.

PLEŠKO, I. - DIBA, CH. S. 2014. Incidencia zhubných nádorov v Slovenskej republike 2008. Bratislava: NCZI, 2014. ISBN 978-80-89292-37-0.

ŠULCOVÁ, M. - ČIŽNÁR, I. - FABIANOVÁ, E. a kol. 2012. Verejné zdravotníctvo. Bratislava: VEDA, 2012. ÚVZ SR: Aktualizovaný program ozdravenia výživy. Dostupné na internete: $<$ http://www.uvzsr.sk/docs/info/hv/ Aktualizovany_Program_ozdravenia_vyzivy.pdf $>$. ISBN 978-80- 224-1283-4.

VILINOVÁ, K. 2012. Zdravotný stav obyvatel'stva Slovenska. Nitra: UKF, 2012. 124 s. ISBN 978-80-558-0058-5.

VILINOVÁ, K. 2012. Priestorové rozšírenie mortality na nádory v Nitrianskom kraji (1997 - 2010). In Geographia Cassoviensis. ISSN 1337-6748, 2012. roč. 6, č. 2 , s. 176-182.

VILINOVÁ, K. et al. 2017. Spatio-Temporal Differentiation of Cancer Incidence in Slovakia. In European Spatial Research and Policy. ISSN 1231-1952, 2017. vol. 24, no. 2, pp. 167-190.

VOBR, R. a kol. 2012. Aplikovana antropomotorika I. Brno: Masarykova univerzita, 2012. $192 \mathrm{~s}$. ISBN 978-80-210-6031-9.

WHITE, M. C. et al. 2014. Age and Cancer Risk A Potentially. In American Journal of Preventive Medicine. ISSN 0749-3797, 2014, vol. 46, no. 3. pp. 715.

TORRE, L. A. et al. 2015. Global cancer statistics 2012. In CA: A Cancer Journal for Clinicians. ISSN 1542-4863, 2015, vol 65, no. 2, pp. 87-108.

TREMBOŠOVÁ, M. - CIVÁŇ, M. - DUBCOVÁ, A. - KRAMÁREKOVÁ, H. 2016. Retail Network and its Perspective (Introduction into the Issuesa). In 23rd Central European Conference on Central Europe Area in View of Current Geography. Brno: MU, 2015. ISBN 978-80-210-7986-1, pp. 292-300.

TREMBOŠOVÁ, M. - VLAČUHOVÁ, V. 2016. Selected Foreing Retail Chains in Slovakia. In 23rd Central European Conference on Central Europe Area in View of Current Geography. Brno: MU, 2015. ISBN 978-80-210-7986-1, pp. 228-237. 
VESELOVSKÝ, J. - ŠOLCOVÁ. 2011. Long-term Unemployment as One of Poverty Indicator on theExample of Nitra Region. In Geographia Cassoviensis. ISSN 1337-6748, 2011. roč. 5, č. 1, s. 119-124.

VESELOVSKÝ, J. - ŠOLCOVÁ, L. - KROGMANN, A. 2016. Rate of Unemployment in the Period Before Crisis as One of the Indicators of Poverty on the Example of the Nitra Region. In 23rd Central European Conference on Central Europe Area in View of Current Geography. Brno: MU, 2015. ISBN 978-80-210-7986-1, pp. 360-365.

ZDRAVIE 21 - Zdravie pre všetkých v 21. storočí. [online]. 2018. [cit. 2018-0909]. Dostupné na internete: http://www.szu.sk/userfiles/file/FVZ/ Katedra\%20riadenia/Zdravotna\%20politika/zdravie_21.pdf

ZÁVODNÁ, K. et al. 2015. Dedičné nádorové syndrómy. In Onkológia [online]. 2015, roč. 10, č. 2. [cit. 2018-09-09]. Dostupné na internete: http://www.onkologiapreprax.sk/index.php?page=pdf_view\&pdf_id=7373\&ma gazine_id=10

ZDRAVIE A ZDRAVOTNÍCTVO NA SLOVENSKU V EURÓPSKOM POROVNANÍ V ROKU 2016 (ANALÝZY A KOMENTÁRE ZALOŽENÉ NA ÚDAJOCH SPRÁVY OECD [online]. 2018 [cit. 2018-09-09]. Dostupné na internete: http://cpldz.sk/2017/01/18/zdravie-a-zdravotnictvo-na-slovenskuv-europskom-porovnani-v-roku-2016/

\section{SPATIAL VARIABILITY OF THE CANCER DISEASES INTENSITY IN SLOVAKIA}

\section{Summary}

Health is the greatest treasure of every individual in today's society. People who have good health have better conditions to achieve their goals than those with various physical and mental difficulties. They create the basic development potential of different hierarchical regions. Tumor diseases in the world's economically advanced countries are the second most common cause of death after cardiovascular disease. These diseases are the main cause of mortality, particularly early and disability, in many regions. The aim of the contribution is to identify, on the basis of mortality and incidence development, regions with a high incidence of cancer.

In Slovakia, over 53,000 people die annually. Of which one fifth for cancer. With the aging of the population and the prolongation of their average life expectancy, their numbers will increase. With the aging of the population and the prolongation of the average life expectancy, every death before the 75th year of life is considered premature. In 2017, 45.06\% of the population died before the age of 75 , of which about one third $(33.74 \%)$ died of cancer. Early on tumor diseases, $62.65 \%$ of the total mortality died (with significant differences between men 
$(60.51 \%)$ and women (39.49\%), and the prevalence of mortality in Slovakia is quite uneven. Although the dominant part of Slovakia's districts is characterized by very low to average mortality rates, 23 out of 79 (29.11\%) districts with high and very high mortality are problematic. In these districts, $30.54 \%$ of the Slovak population, concentrated in two areas - in the central part of Slovakia, and the smaller ones are constituted by the districts of the Podunajská rovina plain. In the decade 2006-2016, 137,563 people died of cancer, of which 78,884 were men and 58,719 were women. The spatial distribution of mortality on cancer has marked differences over overall mortality. Specific mortality is concentrated mainly in the area of agricultural and industrial Podunajská nížina lowland and Východoslovenská nížina lowland. The smaller region consists of the industrial districts of Prievidza and Žilina. High and very high mortality on tumor diseases is in 16 districts, where $37.04 \%$ of the Slovak population lives. Approximately 4,648 people died of this type of disease, accounting for $39.18 \%$ of cancer deaths in Slovakia. According to the National Oncological Registry databases, the incidence of malignant tumors has an upward trend. The number of newly diagnosed cases of illness in Slovakia is rising. While in 1968 it was 12,353 in 2010, it was 32,046. The regions of the Podunajská nížina lowland, Východoslovenská nížina lowland and the Košická kotlina basin are characterized by high numbers of newborn tumors but also by mortality. The Tatra districts of Liptovský Mikuláš, Poprad and Banská Bystrica have a surprisingly high incidence. Very high incidence is in districts with developed industrial production Trnava, Martin, Žilina, Trenčín and Prešov, many of which are characterized by a high mortality rate. A high and very high incidence is threatened by almost one third (23) of Slovakia's districts, in which up to $48.58 \%$ of Slovaks live. In these districts, more than half of the newly diagnosed cases $(51.56 \%$ of the 15,201 incidence cases) of SR were newly registered. High workload, stress low physical load, unhealthy smoking, alcohol as well as predisposition of the individual are signed mainly to increase morbidity.

The good health of the population is the basis for the sustainable economic and social growth of each region and the quality of life of its inhabitants. Health can be disrupted by the influence of influential and unaffordable causes that lead to disease. A large proportion of the population does not pay attention to their health care. Therefore, high emphasis is needed on the issue of prevention and prevention among the population, aimed in particular at reducing unhealthy lifestyles, improving lifestyle, in particular through healthy eating, active physical activity, avoiding alcohol, stress, etc. take preventive examinations, which are extremely important for the detection of early-stage cancers. The prognosis of the patient depends on the early detection of cancer. In order to improve the oncology condition, Slovakia adopted the National Oncology Program (NOP) in 2018 to obtain a tool for preventive activities, the control of morbidity and mortality on oncological diseases, which will be comparable to activities in other EU countries by 2020 . 
Doc. RNDr. Alena Dubcová, CSc.

RNDr. Katarína Vilinová, PhD.

Mgr. Lucia Mikulová

Katedra geografie a regionálneho rozvoja FPV UKF v Nitre

Trieda A. Hlinku 1, 94974 Nitra

E-mail: adubcova@ukf.sk,kvilinova@ukf.sk 